\title{
Bahasa Minang Pondok dalam Komunikasi Antarbudaya Masyarakat Tionghoa Kota Padang
}

\author{
Riniwaty Makmur', Engkus Kuswarno ${ }^{2}$, Evi Novianti ${ }^{3}$, dan Nuryah Asri Syafirah ${ }^{4}$ \\ 1,2,3,4 Universitas Padjadjaran
}

\begin{abstract}
ABSTRAK
Etnik Tionghoa telah ada di Indonesia selama ratusan tahun, tetapi menghadapi beragam permasalahan dalam penerimaan mereka sebagai bagian dari Bangsa Indonesia. Di sisi lain, adaptasi masyarakat etnik Tionghoa di tiap-tiap daerah di Indonesia, memiliki lokalitasnya masing-masing, seperti di Kota Padang dengan evolusi Bahasa Minang Pondok; yang menarik untuk diteliti. Penelitian ini bertujuan menggambarkan faktor-faktor pendorong terjadinya fenomena Bahasa Minang Pondok di Kota Padang, Provinsi Sumatra Barat; dan pola pergeserannya dari bahasa asal, yakni Bahasa Minang. Bahasa Minang Pondok merupakan bahasa yang digunakan oleh masyarakat Tionghoa di Padang, dalam kehidupan sehari-hari. Sementara Bahasa Minang sebenarnya merupakan bahasa dari etnik Minang, kelompok mayoritas di Kota Padang. Penelitian ini merupakan bagian dari sebuah penelitian besar yang menggunakan pendekatan kualitatif/konstruktivis dan metode studi kasus. Pengumpulan data berlangsung secara intermiten/berjeda pada Januari 2016 hingga Juni 2017, melalui observasi di daerah Kampung Pondok/pecinan Kota Padang, wawancara dengan 39 orang informan etnik Tionghoa dan Minang, dan studi literatur. Komunikasi antarbudaya mengenai adaptasi kelompok minoritas, teori kelompok dan batasan etnik dari Frederik Barth, dan Hipotesis Sapir-Whorf, menjadi pijakan teoretis dalam analisis. Penelitian menyimpulkan bahwa Bahasa Minang Pondok terbentuk sebagai produk/hasil penyesuaian masyarakat Tionghoa terhadap etnik mayoritas Minang di Kota Padang agar mendapatkan pemahaman yang sama/komunikasi yang efektif. Bahasa Minang Pondok dicirikan oleh dialek Tionghoa; dengan menghilangkan beberapa cengkok yang ada pada pengucapan/lafal dalam Bahasa Minang. Pola pergeseran dari Bahasa Minang ke Bahasa Minang Pondok terjadi pada aspek fonologis (suara) dan morfologis (bentuk).
\end{abstract}

Kata-kata Kunci: Akulturasi; bahasa minang pondok; komunikasi antarbudaya; padang; tionghoa

\section{Minang Pondok Language in Intercultural Communication of the Chinese Society at Padang City}

\begin{abstract}
The Chinese ethnic group has been in Indonesia hundreds of years, but they face a myriad of problems with regard to their acceptance as a part of the Indonesian people. On the other hand, adaptation by the ethnic Chinese in every area in Indonesia have made their own localization; as they have done in the city of Padang with the evolution of the Minang Pondok Language. This research is aimed at describing the factors that brought about the phenomenon of Minang Pondok Language in Padang City in the Province of West Sumatra; and the pattern of change from the original Minang language. The Minang Pondok Language is the language used by the Chinese community in their daily lives. The Minang language itself is the ethnic language of the Minang people who are the majority community in Padang City. This research is part of an even broader research which used a qualitative/constructive approach and case study method. The data collection took place intermittently between January 2016 and July 2017, consisted of direct observation in the Chinese district of Padang City in Kampung Pondok, by interviewing 39 informants from the Cinese and Minang ethnic communities, and through a study of literature. The intercultural communication with regard to the adaptation by the minority group, the theory of groups and ethnic boundaries from Frederik Barth, and also the hypothesis of Sapir-Whorf were made the theoretical basis for analysis. The research came to the conclusion that the Minang Pondok Language was formed as a product/result of adaptation by the Chinese people towards the majority ethnic Minang group in order to achieve a mutual understanding/ effective communication. The Minang Pondok language is characterised by its Chinese dialect: by leaving out a number of twists which occur in the pronunciation of Minang language. The pattern of shift from Minang language to Minang Pondok language occurs with phonological and morphological aspects.
\end{abstract}

Keywords: Acculturation; chinese; intercultural communication; minang pondok language; padang

Korespondensi: Dr. Riniwaty Makmur, MM., M.Si. Universitas Padjadjaran. Jl. Raya Bandung-Sumedang KM.21 Jatinangor 45363. Email: riniwaty15001@mail.unpad.ac.id 


\section{PENDAHULUAN}

Orang Tionghoa telah berada di Indonesia ratusan tahun lamanya, namun mereka menghadapi beragam permasalahan untuk dapat diterima sebagai orang Indonesia. Kondisi itu terutama disebabkan oleh kebijakan segragasi kolonialisme Belanda di masa lalu, yang memisahkan orang Tionghoa dari orang lokal, yang disebut "pribumi" (Dahana, 2015). Pemisahan itu diterapkan pada banyak bidang seperti pekerjaan, permukiman, status hukum, politik, dan peraturan lainnya. Hampir tidak ada pengertian bersama di dalam hubungan antara orang Tionghoa dan lokal. Satu-satunya komunikasi hanya berlangsung di "pasar". Akibatnya tidak ada saling percaya di antara kedua kelompok, orang Tionghoa dan lokal (Dahana, 2015).

Sayangnya, Pemerintah Indonesia sejak zaman kemerdekaan hingga sebelum reformasi, cenderung melanjutkan kebijakan kolonial itu. Serangkaian gangguan anti orang Tionghoa yang terjadi selama satu abad terakhir, terutama didorong oleh sejarah kebijakan pemisahan pada zaman kolonial Belanda. Stereotip terhadap etnik Tionghoa sebagai orang asing, tidak setia, dan eksploitatif, diperkuat oleh rezim Orde Baru. Orang Tionghoa kerap dijadikan sebagai kambing hitam dalam banyak situasi krisis ekonomi dan politik. Banyaknya korban orang Tionghoa pada tragedi Mei 1998, mengonfirmasi bahwa orang Tionghoa masih belum diterima oleh masyarakat tempat mereka tinggal dan mati yaitu, Indonesia (Chang-Yau Hoon, 2006).

Setelah reformasi tahun 1998, barulah ada hubungan, komunikasi dan penghargaan yang lebih baik di antara kedua kelompok etnik Tionghoa dan lokal. Etnik Tionghoa lebih dihargai sebagai salah satu suku bangsa Indonesia di dalam masyarakat Indonesia yang plural. Banyak yang percaya bahwa Indonesia sekarang sedang berubah dari pluralisme menuju masyarakat multikultural yakni, seluruh kelompok etnik, memiliki hak dan kewajiban yang sama. Namun, hal ini masih harus diperjuangkan. Selain itu, dikatakan oposisi terhadap mantan Gubernur DKI Jakarta Basuki Tjahaja Purnama, merupakan contoh kasus bahwa perasaan anti orang Tionghoa masih ada (Dahana, 2015). Senada dengan itu, survei yang dilakukan Institute of Southeast Asian
Studies (ISEAS) yang berbasis di Singapura tahun 2017, mengafirmasi bahwa sentimen anti Tionghoa di Indonesia belum luntur, malah semakin menguat (Setijadi, 2017).

Anggraeni mengungkapkan bahwa 16 tahun setelah reformasi, prasangka dan ketidakpercayaan masih bersisa di antara etnik Tionghoa dan kelompok masyarakat. Namun di sisi lain, banyak itikad baik telah ditunjukkan oleh masyarakat Indonesia nonTionghoa kepada orang Tionghoa. Itikad baik itu tidak hanya berasal dari orang-orang yang mendapatkan keuntungan dari posisi orang Tionghoa di sektor ekonomi, tetapi juga dari kelompok yang menginginkan keadilan bagi seluruh orang di Indonesia (Anggraeni, 2017). Pendapat yang sama juga disampaikan oleh Suryadinata bahwa sejak reformasi, posisi etnik Tionghoa di Indonesia telah banyak membaik. Namun demikian, prasangka terhadap etnik Tionghoa -meskipun berkurang, tetap berlanjut (Suryadinata, 2018).

Etnik Tionghoa sebenarnya telah beradaptasi dengan masyarakat lokal tempat mereka berada. Salah satu bentuk adaptasi yang paling nyata tampak lewat penguasaan bahasa setempat, seperti terjadi pada orangorang Tionghoa di Kota Padang, Sumatra Barat. Kota Padang merupakan kota terbesar di pantai barat Pulau Sumatra, sekaligus ibukota Provinsi Sumatra Barat, Indonesia. Penduduk Kota Padang didominasi oleh etnik Minangkabau (Minang), yang mayoritas menganut agama Islam. Akan tetapi, Padang bisa dikatakan merupakan kota multietnik. Selain etnik Minangkabau yang merupakan etnik dominan dengan jumlah lebih dari 90\%, di Kota Padang bermukim juga orang-orang dari etnik lain, termasuk etnik Tionghoa. Saat ini, terdapat sejumlah 9.498 orang Tionghoa di Kota Padang, atau hanya $1,1 \%$ dari jumlah seluruh penduduk Kota Padang sebesar 833.562 orang (BPS Kota Padang, 2011).

Masyarakat Tionghoa di Kota Padang kebanyakan berdomisili di daerah pecinan, dikenal dengan nama Kampung Pondok. Erniwati mengatakan, Kampung Pondok telah ada dan menjadi pemukiman Tionghoa sejak masa Hindia Belanda. Kampung Pondok terletak di Kecamatan Padang Barat yaitu Kelurahan Pondok, dan Kecamatan Padang Selatan di Kelurahan Batang Harau. Umumnya daerah pecinan di Padang dikenal hanya dengan nama 
Pondok atau Kampung Pondok. Berkumpulnya warga Tionghoa di Kampung Pondok terkait erat dengan sejarah masa lalu, yang dimulai sejak pemerintahan Hindia Belanda. Belanda (Vereenigde Oostindische Compagniel VOC) menjalankan politik segregasi, dan menentukan tempat domisili bagi pendatang-pendatang Tionghoa agar terpisah dari penduduk lokal (Erniwati, 2016).

Dalam perkembangannya kemudian, daerah pemukiman itu menjadi permanen, dan juga menjadi pusat kehidupan komunitas etnik Tionghoa. Kelenteng, rumah duka, gedunggedung perkumpulan etnik Tionghoa (Kongsi), bahkan pemakaman (sebelum dipindahkan oleh Pemerintah Kota Padang tahun 2000), berada dalam lingkungan Kampung Pondok. Seiring berjalannya waktu, banyak perubahan terjadi di Kota Padang termasuk pada pola bertempat tinggal orang-orang etnik Tionghoa. Beberapa hal yang mendorong perubahan adalah berkembangnya pemukiman-pemukiman baru di Kota Padang (di luar pecinan) dengan harga terjangkau, dan gempa besar tahun 2009 yang meluluh-lantakkan sebagian besar pecinan. Situasi tersebut telah mendorong cukup banyak orang Tionghoa untuk pindah mencari rumah tinggal keluar dari pecinan.

Sementara itu etnik Minangkabau (Minang) yang merupakan etnik mayoritas berdomisili merata di seluruh Kota Padang, termasuk di wilayah Kampung Pondok (pecinan/ daerah pemukiman orang Tionghoa). Etnik Minang yang dimaksud pada penelitian ini adalah masyarakat yang berasal dari suku Minangkabau dan berdomisili di Kota Padang, Sumatra Barat. Dalam percakapan awam, orang Minang seringkali disamakan sebagai orang Padang, merujuk pada nama ibu kota provinsi Sumatra Barat, yakni Kota Padang. Setiap orang Minang bisa mengaku sebagai orang Padang, tetapi tidak setiap orang Padang bisa mengaku orang Minang (Elfira, 2011). Suku Minangkabau merupakan kelompok etnik ketujuh terbesar di Indonesia, dengan jumlah sekitar 6,5 juta orang (Badan Pusat Statistik, 2011). Jumlah terbesar ada di Sumatra Barat, di mana mereka membentuk lebih dari $90 \%$ populasi kota Padang, atau sejumlah 757.025 orang (BPS Kota Padang, 2016).

Salah satu fakta menarik dari situasi di Kota Padang adalah hubungan antara etnik Tionghoa dan Minang di Kota Padang, relatif jauh dari konflik. Namun demikian, Alfirdaus, Hiariej, \& Adeney-Risakota, mengungkapkan bahwa relasi kedua etnik dinamis, ada ketegangan tetapi juga ada kerjasama. Ikatan yang terjalin di antara kedua etnik, salah satunya mungkin terbentuk karena kesamaan bahasa sehari-hari (Alfirdaus, Hiariej, \& Adeney-Risakotta, 2014 \& 2016). Pemahaman akan bahasa merupakan hal penting, karena bahasa terjadi dalam kehidupan sehari-hari, dan berperan dalam komunikasi. Tanpa bahasa, tidak mungkin terjadi komunikasi (Samovar, Porter, \& McDaniel, 2010). Ini juga salah satu alasan, studi mengenai etnik Tionghoa di Kota Padang menarik untuk dilakukan, khususnya menyangkut adaptasi mereka melalui bahasa.

Etnik Minang menggunakan bahasa Minang dalam percakapan sehari-hari, dan demikian juga etnik-etnik lain di Padang, termasuk orang Tionghoa. Dengan perkataan lain, bahasa Minang adalah bahasa pengantar/ sehari-hari di Kota Padang. Namun, bahasa Minang yang digunakan komunitas etnik Tionghoa, agak berbeda dari aslinya karena telah disesuaikan dengan dialek orang Tionghoa, sehingga dikenal dengan fenomena bahasa Minang Pondok. "Pondok" mengacu pada Kampung Pondok. Semua orang Tionghoa di Padang berkomunikasi lewat bahasa Minang Pondok, atau bahasa Indonesia. Kebanyakan orang Tionghoa di Kota Padang tidak bisa lagi menggunakan bahasa Mandarin atau dialek Tionghoa lainnya. Fenomena bahasa Minang Pondok di Kota Padang adalah hasil nyata dari upaya adaptasi etnik Tionghoa terhadap etnik mayoritas Minangkabau, yang telah berlangsung ratusan tahun.

Fenomena adopsi bahasa lokal oleh orang Tionghoa terjadi di berbagai wilayah di Indonesia. Akan tetapi, Erniwati mengatakan adaptasi etnik Tionghoa di berbagai daerah di Indonesia merupakan hal yang unik, dalam arti hampir tidak ada yang sama di tiap daerah. Ia memakai istilah "lokalitas" untuk mendeskripsikan situasi etnik Tionghoa di berbagai kota/daerah di Indonesia. Dengan lokalitas itu maka kendati terdapat fenomena yang sama, setiap daerah akan memiliki keunikan masing-masing (Erniwati, 2011). Temuan yang sama dilaporkan Septia, lewat penelitiannya mengenai bahasa pedagang etnik Tionghoa di Pondok (pecinan), Kota Padang, menyebutkan adanya kekhasan penggunaan 
bahasa Minangkabau oleh pedagang etnik Tionghoa (Septia, 2017). Adapun Hapsari meneliti mengenai tindak tutur permintaan maaf pada masyarakat Tionghoa di Padang (Hapsari, 2013). Ia menemukan bahwa di Kampung Pondok, orang Tionghoa berkomunikasi dengan bahasa Minang dialek Tionghoa, dan terdapat perbedaan pada beberapa kosakata dan partikel bahasa yang digunakan dari bahasa Minang. Keunikan yang ada di Kota Padang, Sumatra Barat, sehubungan dengan evolusi bahasa Minang Pondok pada komunitas etnik Tionghoa, akan menjadi fokus penelitian ini. Penelitian sejenis mengenai bahasa Minang Pondok tidak/ belum ditemukan, sehingga penelitian ini bisa jadi yang pertama kali dilakukan.

Etnik Tionghoa pada penelitian ini mengacu pada orang-orang keturunan atau suku Tionghoa yang bermukim di daerah Pondok, di Kota Padang, Sumatra Barat. Masyarakat etnik Tionghoa sebagai migran/kelompok minoritas di Kota Padang, tidak hidup di dalam isolasi. Mereka berada dan menjadi bagian dari masyarakat beragam etnik, termasuk etnik mayoritas Minangkabau (Minang). Mengacu kepada Barth, interaksi etnik Tionghoa dengan etnik Minang mempengaruhi identitas kelompok orang Tionghoa di Padang (Barth, 1998). Identitas itu merupakan sebuah konstruksi yang tidak terlepas dari pengaruh lokal Minangkabau seperti terjadi pada bahasa mereka. Dengan perkataan lain, bahasa Minang Pondok yang digunakan oleh komunitas etnik Tionghoa di Kota Padang, merupakan hasil atau produk dari interaksi etnik Tionghoa dengan etnik mayoritas yaitu, Minangkabau.

Ratusan tahun yang lalu sebagai pendatang, orang Tionghoa menghadapi tantangan perbedaan bahasa, kebiasaan, dan praktik kebudayaan lainnya di tempat mereka yang baru di Kota Padang. Mereka harus beradaptasi atau menyesuaikan diri agar bisa diterima oleh masyarakat di lingkungannya yang baru. Proses pembelajaran untuk hidup dalam budaya yang baru itu merupakan akulturasi, yakni proses dari perubahan budaya dan psikologis yang terjadi sebagai akibat dari hubungan antara dua atau lebih kelompok budaya dan anggotanya (Samovar, Porter, \& McDaniel, 2010). Pembelajaran ini merupakan proses yang panjang dan membutuhkan banyak pengetahuan mengenai budaya baru, termasuk penguasaan bahasa. Penelitian tentang pelajar imigran dari Tiongkok di Australia (Gao, 2000) menyimpulkan bahwa, sekali seseorang menguasai bahasa lokal dengan lebih baik, ia juga mengetahui budaya setempat lebih baik. Inilah yang dimaksud dengan akulturasi.

Keterbatasan bahasa bisa menjadi penghalang yang besar dalam penyesuaian dan komunikasi antarbudaya yang efektif (Samovar, Porter, \& McDaniel, 2010). Komunikasi antarbudaya terjadi ketika anggota dari satu budaya tertentu memberikan pesan kepada anggota dari budaya yang lain. Collier mengungkapkan bahwa untuk dapat berkomunikasi secara efektif dalam situasi antarbudaya, identitas budaya yang diakui seseorang serta gaya komunikasinya harus sesuai dengan identitas dan gaya yang ditampilkan padanya oleh lawan bicaranya. Namun, karena gaya komunikasi mungkin berbeda, masingmasing pelaku komunikasi harus mencari jalan tengah, dan pencarian itu membutuhkan fleksibilitas dan adaptasi (Samovar, Porter, \& McDaniel, 2010).

Penelitianiniberargumenbahwamasyarakat komunitas etnik Tionghoa di Padang secara umum telah menempuh jalan tengah (fleksibel dan adaptif) dalam berkomunikasi dengan etnik mayoritas Minangkabau. Hal itu tercermin melalui evolusi bahasa Minang Pondok. Namun demikian, kebudayaan yang berasal dari identitas etnik mereka yaitu Tionghoa, tidak sepenuhnya hilang dan itu tampak melalui dialek Tionghoa dalam pengucapan/bahasa verbal pada pemakaian bahasa Minang Pondok. Inilah yang membentuk kekhasan bahasa Minang Pondok, sehingga menarik diteliti.

Bahasa merupakan sejumlah simbol atau tanda yang disetujui untuk digunakan oleh sekelompok orang untuk menghasilkan arti (Samovar, Porter, \& McDaniel, 2010; Mulyana, 2015). Bahasa terbentuk dari sistem terstruktur, suara vokal yang arbitrer dengan mana sejumlah orang telah belajar untuk menggunakannya sebagai alat untuk memberikan nama/label dan mengkategorikan benda-benda, proses-proses, dan pengalaman-pengalaman dari lingkungan mereka (Samovar, Porter \& Jain, 1981). Fungsi bahasa menurut Mulyana, adalah untuk mengenal dunia di sekitar kita, berhubungan dengan orang lain, dan menciptakan koherensi (pemahaman) dalam kehidupan kita (Mulyana, 2015).

Bahasa Minang Pondok adalah bahasa 
Minang yang dalam pemakaiannya mengalami penyesuaian/pergeseran mengikuti dialek orang Tionghoa. Jadi bahasa Minang Pondok pada dasarnya adalah bahasa Minang yang mengalami penyesuaian ketika dipakai oleh orang Tionghoa. Pembeda yang paling nyata antara bahasa Minang dan Minang Pondok adalah suara atau bunyi pengucapannya. Berdasarkan uraian di atas, permasalahan pada penelitian ini dirumuskan sebagai berikut: Mengapa bahasa Minang Pondok bisa menjadi bahasa sehari-hari masyarakat Tionghoa di Kota Padang? Serta, bagaimana pola pergeseran bahasa Minang menjadi bahasa Minang Pondok?

\section{METODE PENELITIAN}

Penelitian ini merupakan bagian dari sebuah penelitian besar secara kualitatif/konstruktivis dengan metode studi kasus. Denzin dan Lincoln mengatakan paradigma konstruktivis secara ontologis realitasnya bersifat relativis. Pada aspek epistemologi, penelitian konstruktivis bersifat transaksional dan subjektivis. Sementara itu dari segi metodologi, penelitian konstruktivis adalah hermeneutika, mengandalkan kinerja interpretasi dan dialektis antara peneliti dan informan. Subjek penelitian adalah masyarakat etnik Tionghoa di Kota Padang. Sedangkan objek penelitian adalah bahasa yang mereka pakai dalam proses komunikasi verbal seharihari (Denzin \& Lincoln, 2009).

Pada penelitian studi kasus peneliti mengeksplorasi kehidupan nyata, sistem terbatas kontemporer (kasus) atau beragam sistem terbatas (berbagai kasus), melalui pengumpulan data yang detail dan mendalam yang melibatkan beragam sumber informasi atau sumber informasi majemuk seperti pengamatan, wawancara, dan dokumen berbagai laporan, dan melaporkan deskripsi kasus dan tema kasus (Creswell, 2014).

Pengumpulan data pada penelitian ini dilakukan secara berselang/berjeda pada rentang waktu antara Januari 2016 hingga Juni 2017 (sekitar 15 bulan). Lokasi penelitian dibatasi pada kawasan pecinan Kota Padang, yang dikenal juga dengan nama Kampung Pondok. Disebutkan pengumpulan data sebagai rangkaian aktivitas yang saling terkait dan bertujuan untuk mengumpulkan informasi guna menjawab pertanyaan-pertanyaan penelitian yang muncul (Creswell, 2014). Dalam penelitian ini, pengumpulan data dilakukan pada kondisi yang alamiah, dan sumber data primer serta sekunder. Penelitian menggunakan teknik pengumpulan data melalui pengamatan/ observasi, wawancara, telaah dokumen, dan juga triangulasi (Sugiyono, 2015).

Observasi dilakukan di berbagai lokasi relevan di kawasan pecinan di Kota Padang, termasuk di rumah perkumpulan etnik Tionghoa (Kongsi) Himpunan Bersatu Teguh (HBT), rumah duka HBT, kelenteng, warung kopi, dan Pasar Tanah Kongsi (pasar di daerah Kampung Pondok). Khusus mengenai topik ini yaitu, pemakaian bahasa Minang Pondok, Peneliti mengumpulkan kosa kata yang ditemukan/ dipakai dalam percakapan oleh orang Tionghoa di Padang sebagai data penelitian. Percakapan terjadi di dalam berbagai situasi, baik di dalam keluarga, di pasar, ketika melayat, di warung, di Kongsi, dan di kelenteng. Data kosa kata juga dibangun berdasarkan diskusi dan dukungan mahasiswa jurusan sastra di lapangan.

Sementara itu, teknik penentuan informan kunci dilakukan dengan menggunakan purposive sample (sampel bertujuan) dan prosedur bola salju. Teknik ini bermanfaat dalam hal memperluas informasi yang telah diperoleh terlebih dahulu, sehingga dapat dipertentangkan atau diisi seandainya ada kesenjangan informasi yang ditemui. Moleong mengatakan dari mana atau dari siapa sampel dimulai tidak menjadi persoalan, tetapi bila hal itu sudah berjalan, maka pemilihan berikutnya bergantung pada apa keperluan peneliti (Moleong, 2015). Pada teknik bola salju, unit sampel yang dipilih makin lama makin terarah sejalan dengan makin terarahnya fokus penelitian (Sugiyono, 2015). Melalui prosedur snowball, Peneliti mewawancarai 39 orang informan, terdiri dari 26 orang etnik Tionghoa dan 13 orang etnik Minang sebagai pendukung. Nama-nama informan disamarkan untuk menjaga identitas mereka. Sebagai pelengkap wawancara dan observasi, Peneliti juga mengumpulkan dan mempelajari literatur dari berbagai sumber, termasuk secara online.

Proses analisis data dalam penelitian kualitatif dilakukan sejak sebelum memasuki lapangan, selama di lapangan, dan setelah selesai melakukan kerja lapangan (Sugiyono, 2015). Analisis data dilakukan secara deskriptif mengikuti konsep analisis kualitatif (Moleong, 2015), yakni upaya yang dilakukan dengan jalan bekerja dengan data, mengorganisasikan 
data, memilah-milahnya menjadi satuan yang dapat dikelola, mensintesiskannya, mencari dan menemukan pola, menemukan apa yang penting dan apa yang dipelajari, dan memutuskan apa yang dapat diceritakan kepada orang lain.

Pada analisis data kosa kata bahasa Minang Pondok, data yang sudah terkumpul dilihat pola pergeserannya berdasarkan pengucapan/ pelafalan oleh orang Tionghoa. Irawan mengatakan, ketika suatu kelompok tidak lagi memakai bahasa pertamanya dan bergeser atau pindah ke bahasa kedua yang lebih dominan, bahasa tersebut akan mengalami pergeseran bahasa (Irawan, 2014). Definisi pergeseran bahasa (language shift) menurut Chaer menyangkut masalah penggunaan bahasa oleh seorang penutur atau sekelompok penutur yang bisa terjadi sebagai akibat perpindahan dari satu masyarakat tutur ke masyarakat tutur yang lain (Irawan, 2014).

\section{HASIL DAN PEMBAHASAN}

Setiap laporan atau cerita mengenai orang Tionghoa di Kota Padang biasanya menyebutkan mengenai bagaimana orangorang Tionghoa tersebut tidak bisa lagi bahasa Mandarin dan berkomunikasi dengan memakai bahasa Minang. Bagi orang-orang yang bukan berasal dari daerah Sumatra Barat, atau tidak mengenal bahasa Minang, mungkin tidak akan bisa membedakan bahasa Minang yang digunakan oleh masyarakat Tionghoa dengan bahasa Minang yang digunakan oleh Suku
Minang. Sebenarnya terdapat perbedaan pada bahasa Minang yang dipakai oleh orangorang Tionghoa, karena telah disesuaikan dengan dialek orang Tionghoa, sehingga ada istilah bahasa Minang Pondok untuk bahasa sehari-hari yang mereka gunakan. "Pondok" mengacu pada Kampung Pondok, yaitu daerah pecinan (pemukiman orang Tionghoa) di Kota Padang. Bahasa Minang Pondok membentuk identitas "baru" pada orang Tionghoa di Padang. Penggunaan bahasa setempat/Minang dan "hilangnya" kemampuan berbicara bahasa ibu, menunjukkan bahwa konstruksi identitas orang Tionghoa di Padang, telah mendapatkan pengaruh dari faktor eksternal, yakni budaya lokal Minangkabau (Barth, 1998).

Bahasa Minang Pondok dipakai tidak hanya untuk berbicara dengan orang non-Tionghoa, tetapi juga dalam pembicaraan di antara orang Tionghoa pada umumnya, antara orang tua dengan anak-anaknya, di pasar, dan di dalam pergaulan. Untuk mengetahui mengapa orangorang Tionghoa di Padang, sangat dipengaruhi oleh bahasa Minang, maka perlu meninjau situasi orang Tionghoa di Kota Padang dan lingkungan sekitarnya.

Wilayah pecinan atau Kampung Pondok terletak pada dua kecamatan dan kelurahan (Gambar 1). Keduanya adalah Kecamatan Padang Barat, Kelurahan Kampung Pondok, dan Kecamatan Padang Selatan, Kelurahan Batang Harau.

Seluruh wilayah yang berbatasan dengan Kota Padang masih merupakan bagian

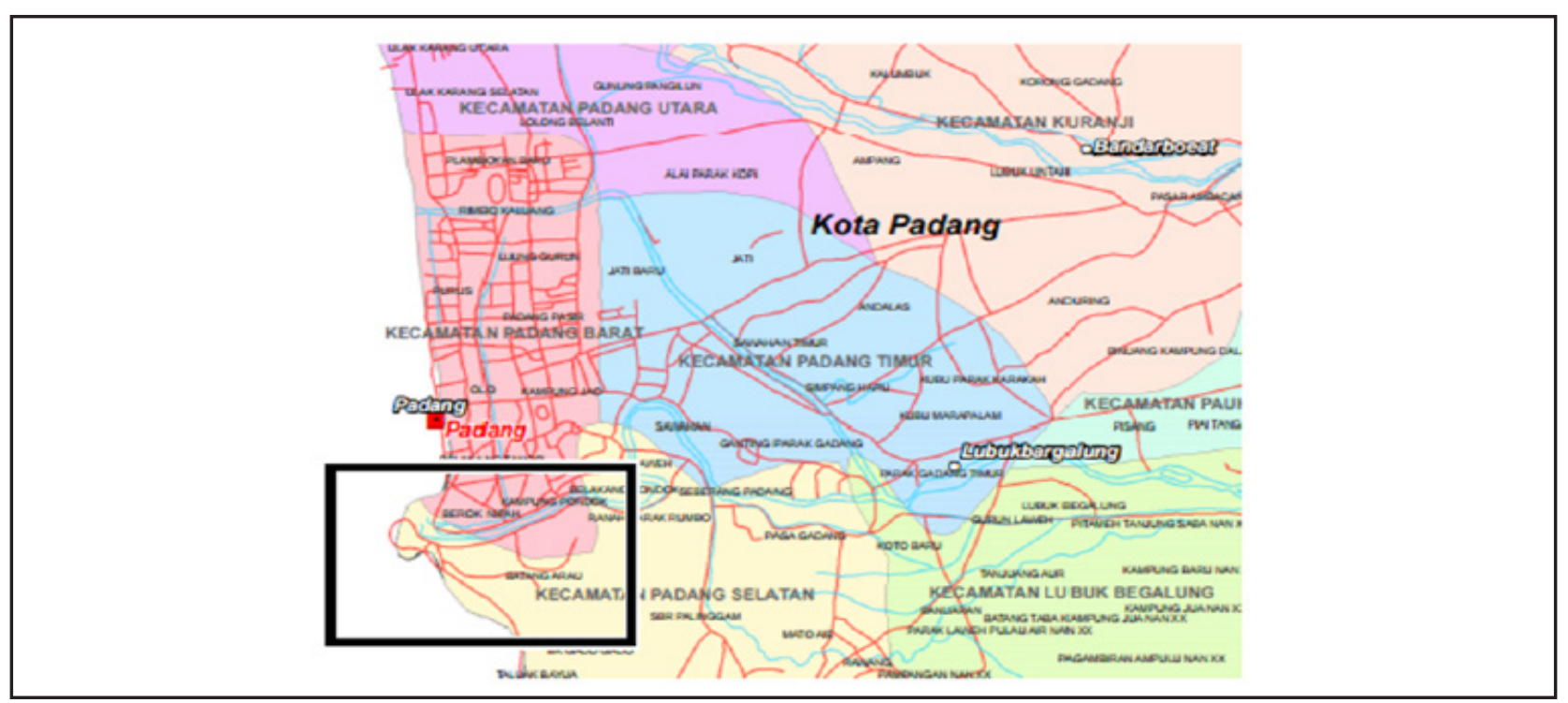

Sumber: BNPB, 2017

Gambar 1 Perkiraan Denah Daerah Pecinan (Kampung Pondok) Kota Padang (Kotak). 
dari Provinsi Sumatra Barat. Penduduknya berkomunikasi menggunakan bahasa Minang. Perbatasan beda wilayah yang terdekat dengan Kota Padang adalah Kota Pekanbaru di Provinsi Riau. Di Provinsi Riau, bahasa yang umum digunakan adalah bahasa Indonesia, Melayu dan juga bahasa Minang. Namun khusus di Kota Pekanbaru, bahasa Minang lebih dominan daripada bahasa Melayu karena sebagian besar penduduk Kota Pekanbaru berasal dari Sumatra Barat (Jelprison, 2010). Mereka kebanyakan berprofesi sebagai pedagang. Keadaan ini didukung oleh data statistik persentase suku bangsa yang ada di Pekanbaru (Rachmazan, 2017). Suku Minang terbesar dengan persentase $37,7 \%$, diikuti oleh Melayu (26,1\%), Jawa $(15,1 \%)$, Batak $(10,8 \%)$, Banjar $(0,2 \%)$, Bugis $(0,2 \%)$, Sunda $(1,0 \%)$, dan suku-suku lainnya $(8,8 \%)$.

Jadi, Kota Padang sangat dipengaruhi oleh bahasa Minang, karena suku Minang dominan baik di Padang, dan daerah di sekitarnya/ perbatasan. Situasi itu memberikan gambaran mengapa orang Tionghoa di Padang terpengaruh oleh bahasa Minang. Bahasa Minang dan bahasa Indonesia, atau percampuran kedua bahasa menjadi bahasa sehari-hari di Kota Padang. Bahasa Indonesia digunakan dalam situasi formal, misalnya proses pengajaran di sekolahsekolah. Bahasa di kantor-kantor swasta dan pemerintah, umumnya menggunakan bahasa Indonesia, tetapi sering juga diselingi oleh bahasa Minang.

Sementara di daerah pecinan/Kampung Pondok, bahasa Minang mengalami sedikit penyesuaian atau dalam istilah linguistik, pergeseran ke bahasa Minang Pondok. Seluruh orang Tionghoa di Kota Padang, bisa berbahasa Minang Pondok yang merupakan bahasa pengantar sehari-hari. Masyarakat Minang tidak mempermasalahkan pergeseran bahasa Minang ke bahasa Minang Pondok. Bahkan ketika berada di Kampung Pondok (pecinan), tidak jarang orang Minang ikut memakai bahasa Minang Pondok. Selain bahasa Minang Pondok, bahasa lain yang dipakai oleh komunitas Tionghoa di Padang adalah bahasa Indonesia. Jika ada orang Tionghoa di Kota Padang yang sulit berbahasa Minang, maka kemungkinan besar mereka adalah perantau dari daerah Medan, atau pesisir Provinsi Riau/ Kepulauan Riau.

Kenyataan bahwa masyarakat etnik Tionghoa di Kota Padang kebanyakan tidak bisa berbahasa Mandarin, dan hanya menggunakan bahasa Minang Pondok; menjadi bukti dari pelaksanaan kebijakan asimilasi Pemerintah Orde Baru. Oetomo mengungkapkan bahwa hilangnya kemampuan berbahasa ibu (bahasa etnik) dari kelompok minoritas merupakan salah satu indikasi dari terjadinya paradigma asimilasi (kebudayaan tuan rumah lebih dihargai daripada kebudayaan migran) (Oetomo, 1987). Bahasa berperan dalam membentuk, menyatakan, dan mempertahankan identitas (Samovar, Porter, \& McDaniel, 2010). Kebijakan politik Orde baru itu menjadi faktor kedua yang diidentifikasi sebagai pendorong evolusi/ pemakaian bahasa Minang Pondok di kalangan orang Tionghoa di Padang. Faktor pertama adalah lokasi Kota Padang dan pengaruh orang Minang yang dominnan baik di Padang, dan wilayah yang berbatasan dengan Kota Padang, seperti dipaparkan sebelumnya.

Politik asimilasi yang dijalankan secara terbuka oleh Pemerintahan Orde Baru di bawah Presiden Soeharto, berdampak besar terhadap orang Tionghoa (Suryadinata, 2018). Soeharto melarang tiga pilar utama kebudayaan Tionghoa, yaitu: pers berbahasa Tionghoa, sekolah-sekolah menengah Tionghoa, dan organisasi-organisasi etnik Tionghoa. Akibatnya, keturunan orang Tionghoa totok, yang tadinya bisa berbahasa Tionghoa, berubah menjadi tipe baru Tionghoa peranakan yang menggunakan bahasa Indonesia sebagai bahasa sehari-hari.

Suryadinata mengungkapkan bahwa sebelum Perang Dunia II, orang Tionghoa dibagi menjadi "Tionghoa peranakan" dan "Tionghoa totok" (atau Tionghoa migran). Tionghoa peranakan mengacu pada orang Tionghoa yang lahir di Indonesia dan dipengaruhi oleh budaya lokal (Melayu/Indonesia) (Suryadinata, 2018). Mereka biasanya kehilangan kemampuan berbahasa Tionghoa, dan menggunakan dialek lokal atau bahasa Indonesia dalam percakapan sehari-hari. Sementara Tionghoa totok, yang datang pada abad ke-20, biasanya masih mempertahankan budaya dan bahasa Tionghoa, dan menggunakannya dalam komunikasi seharihari. Anak-anak mereka yang lahir di Indonesia, juga masih memiliki kedekatan dengan budaya dan bahasa Tionghoa, karena bersekolah di sekolah menengah Tionghoa. Namun sekolahsekolah Tionghoa ditutup oleh Pemerintah Orde Baru pada tahun 1967. Tionghoa totok, yang lahir di Tiongkok tentu sudah tidak ada lagi 
karena tidak ada periode kedatangan migran baru. Adapun generasi Tionghoa yang lahir di Indonesia pada tahun 1960-an, banyak yang tidak bisa lagi berbahasa Tionghoa karena pelarangan tiga pilar utama kebudayaan Tionghoa tadi. Situasi itu memperkuat hilangnya kemampuan berbahasa Mandarin/dialek Tionghoa lain pada masyarakat Tionghoa.

Faktor politik selama Orde baru ternyata berpengaruh besar pada eksistensi bahasa. Tidak hanya bahasa orang Tionghoa, tetapi salah satu penelitian menemukan bahwa Indonesianisasi pada masa Orde Baru, dan kebijakan bahasa nasional ternyata berdampak negatif terhadap eksistensi bahasa suku minoritas Rongga di daerah Flores (Arka, 2011). Arka mengungkapkan penerapan kebijakan politis Orde Baru di tingkat bawah (pada zaman dahulu di Flores), misalnya melalui hukuman yang diberikan kepada murid bila memakai bahasa daerah di sekolah adalah sesuatu yang berlebihan dan berdampak buruk terhadap persepsi dan kelangsungan bahasa daerah.

"Indonesianisasi" lewat bahasa seperti ditemukan oleh penelitian di NTT itu juga disebutkan oleh Suryadinata. Ia mengatakan bahwa berbagai kelompok etnik berbeda di Indonesia telah "dinasionalisasi" oleh Pemerintah Orde Baru lewat pembelajaran bahasa Indonesia. Fakta itu didukung oleh hasil sensus penduduk tahun 2010, yang menunjukkan lebih dari 92\% orang Indonesia bisa berbahasa Indonesia (Suryadinata, 2018). Namun yang menarik, mereka yang menggunakan bahasa Indonesia sebagai bahasa sehari-hari ternyata hanya $19,95 \%$. Sedangkan sebagian besar orang Indonesia terus berbicara dalam bahasa etnik/suku mereka, kecuali tiga kelompok etnik: Betawi, Tionghoa, dan Batak (Suryadinata, 2018).

Selain "pelarangan" bahasa Tionghoa di masa Orde Baru, faktor ketiga yang berpengaruh pada pemakaian bahasa Minang Pondok yang meluas adalah, banyak orang Tionghoa yang tidak menggunakan atau mengajarkan bahasa Mandarin/dialek Tionghoa lain kepada anakanak mereka. Pengalaman peneliti (dan banyak orang lain), kedua orang tua peneliti adalah guru di Sekolah Tionghoa, dan mereka bisa berbicara dan menulis dalam bahasa Mandarin. Namun, kami anak-anak mereka tidak ada satu pun yang bisa berbahasa Mandarin, karena di rumah yang digunakan adalah bahasa Indonesia/Minang
Pondok. Kejadian serupa bisa jadi dialami oleh banyak keluarga Tionghoa di Kota Padang. Padahal, paksaan dari orang tua/kakek nenek untuk berbicara dalam bahasa ibu (dalam kasus ini bahasa Mandarin/dialek Tionghoa lainnya), atau pengaruh keluarga, juga menentukan kemampuan seseorang berbahasa etnik/ sukunya.

Faktor keempat yang mendorong hilangnya pemakaian bahasa Mandarin atau dialek Tionghoa lain dari kalangan masyarakat Tionghoa di Kota Padang, adalah jumlah orang Tionghoa yang sedikit. Orang Tionghoa hanya sekitar 1\% dari total populasi, sementara jumlah orang Minang yang mayoritas mencapai lebih 90\%. "Jadi ke mana pergi, yang didengar bahasa Minang," ujar informan (S), seorang tokoh masyarakat Tionghoa yang sempat mengecap pendidikan di sekolah Tionghoa. Kondisi itu 'memaksa' komunitas etnik Tionghoa untuk berbahasa Minang, di samping juga aspek kepatuhan terhadap peraturan pemerintah yang melarang penggunaan bahasa Mandarin pada masa pemerintahan Orde Baru.

Sementara di kota lain, seperti Medan yang pemakaian bahasa Mandarin/Hokkian masih banyak, tidak ada satu suku yang sangat dominan. Di Kota Medan, Sumatra Utara, populasi terbesar adalah Suku Jawa (33\%), Tionghoa sekitar 25\% (Lubis, 2012), dan selebihnya dalam persentase $3-11 \%$ terbagi atas suku Sunda, Karo, Mandailing, Minangkabau, Aceh, dan lain-lain. Lubis melakukan penelitian mengenai komunikasi antarbudaya etnis Tionghoa dan pribumi di Kota Medan, mengungkapkan bahwa hampir seluruh informannya bisa berbahasa Mandarin/ Hokkian (Lubis, 2012). Mereka juga setiap hari berkomunikasi memakai bahasa Mandarin/ Hokkian, jika situasi memungkinkan. Dari kasus itu, dapat dikatakan bahwa wilayah di mana terdapat satu suku dengan jumlah sangat dominan seperti di Kota Padang, maka bahasa yang digunakan cenderung akan mengikuti bahasa dari suku yang dominan tadi.

Sedangkan faktorsosial ekonomitampaknya tidak berpengaruh pada pemakaian bahasa Minang Pondok di kalangan orang Tionghoa di Kota Padang. Tidak ada pengelompokan bahasa berdasarkan keadaan sosial ekonomi seseorang yang bisa diidentifikasi. Situasi yang dialami dari sejarah perjalanan bangsa Indonesia, menimpa masyarakat di Padang 
tanpa melihat kelas sosial ekonomi, sehingga semuanya rata-rata berkomunikasi lewat bahasa Minang Pondok atau bahasa Indonesia. Situasi ini berbeda dengan hasil penelitian Arka, yang memaparkan bahwa ketahanan bahasa suatu kelompok menjadi rentan salah satunya disebabkan oleh kemiskinan. Hal ini mungkin karena lokasi penelitiannya di NTT, salah satu provinsi termiskin di Indonesia. Masyarakat lebih memprioritaskan urusan perut daripada bahasa dan budaya (Arka, 2011). Sedangkan Padang, kota pelabuhan yang ramai bahkan merupakan wajan percampuran multietnik. Situasi di Padang, lebih banyak didorong oleh faktor politis daripada ekonomi.

Di satu sisi, cukup banyak yang menyayangkan kenyataan bahwa seseorang melupakan bahasa ibunya. Namun di sisi lain, pemakaian bahasa setempat diakui juga, telah mendukung pada kohesivitas dan keharmonisan hubungan dengan masyarakat lokal. Fakta itulah yang tampak pada posisi dan hubungan masyarakat etnik Tionghoa dengan kelompok mayoritas Minang. Penggunaan bahasa yang sama dengan kelompok etnik lain dalam kehidupan sehari-hari, mendukung dalam membangun suasana yang lebih harmonis pada pergaulan antaretnik. Ini membuktikan efektivitas adaptasi atau proses akulturasi (pembelajaran budaya baru) dalam komunikasi antarbudaya. Akulturasi orang-orang Tionghoa melalui penguasaan bahasa Minang Pondok memberikan mereka kekhasan, dan mendukung pada komunikasi antarbudaya yang sukses antara etnik Tionghoa dan etnik Minangkabau.

Adaptasi/penyesuaian adalah kata yang sering diulang-ulang oleh beberapa Informan kunci dalam wawancara, dan menjadi faktor kelima dan paling menentukan yang mendorong adopsi bahasa Minang oleh orang Tionghoa. Hal itu disampaikan oleh informan $(\mathrm{Tj})$, pimpinan sebuah perkumpulan etnik Tionghoa di Padang, katanya, "Kita (masyarakat Tionghoa) menyesuaikan dengan keadaan yang berkembang." Bersikap fleksibel dan melakukan penyesuaian/adaptasi, disadari sekali oleh komunitas Tionghoa di Kota Padang merupakan faktor penting dalam berbaur dan menjaga kehidupan yang harmonis dan kohesivitas hubungan antaretnik. Temuan serupa juga dilaporkan oleh Heryadi \& Silvana, melalui penelitian mereka tentang adaptasi masyarakat etnik Sunda terhadap etnik Rejang di daerah imigrasi Permu, Provinsi Bengkulu. Heryadi \& Silvana mengatakan Penduduk dari etnik Sunda sudah beradaptasi dengan budaya Rejang sehingga saat berinteraksi dengan orang Rejang sudah tidak ada lagi hambatan yang berarti. Pada kasus itu, orang Sunda merupakan kelompok pendatang (Heryadi \& Silvana, 2013).

Pada umumnya jalan tengah akan diambil oleh kelompok pendatang/minoritas sebagai pihak yang harus mengalah atau fleksibel dan melakukan adaptasi. Kenyataan ini selaras dengan pernyataan Collier bahwa masingmasing pelaku komunikasi harus mencari jalan tengah agar dapat berkomunikasi secara efektif dalam situasi antarbudaya (Samovar, Porter, \& McDaniel, 2010). Pencarian jalan tengah ini membutuhkan fleksibilitas dan adaptasi (Samovar, Porter, \& McDaniel, 2010). Situasi itulah yang terjadi pada komunitas etnik Tionghoa di Padang secara umum, yang telah menempuh jalan tengah (fleksibel dan adaptif) dalam berkomunikasi dengan etnik mayoritas Minangkabau, dan melahirkan bahasa Minang Pondok.

Bahasa Minang Pondok merupakan bahasa Minang dengan dialek Tionghoa, sehingga terdengar unik/khas. Hal itu menyebabkan bahasa Minang Pondok menjadi ciri dalam identitas etnik Tionghoa di Kota Padang. Penggunaan bahasa Minang Pondok di kalangan komunitas Tionghoa di Padang, juga menunjukkan adanya pengaruh faktor eksternal yang berasal dari budaya Minang. Situasi itu setala dengan pernyataan Barth bahwa interaksi kelompok etnik tertentu dengan kelompok etnik lain merupakan faktor pembentuk kelompok etnik tersebut. Faktanya memang orang Tionghoa telah ratusan tahun berinteraksi dengan masyarakat Minang (Barth, 1998).

Pembeda yang nyata secara umum antara bahasa Minang Pondok dengan bahasa Minang adalah suara vokal atau pelafalan/pengucapan. Suara/ucapan-ucapan dalam bahasa Minang Pondok tidak semedok bahasa Minang. Jika penutur asli bahasa Minang memiliki cengkokcengkok yang khas dalam pengucapan bahasa Minang, maka di dalam bahasa Minang Pondok, cengkok tadi cenderung menjadi lurus dengan mengganti bunyi vokal. Penghilangan cengkok menyebabkan bunyi ucapan dalam bahasa Minang Pondok tidak semedok bahasa Minang, atau menghilangkan cengkok khas 
Minang. Irawan menjelaskan mengenai fenomena pergeseran bahasa ketika diadopsi oleh kelompok pendatang (Irawan 2014): "Pada kelompok imigran lebih sering terjadi suatu pergeseran bahasa jika dibandingkan dengan masyarakat aslinya disebabkan karena imigran berpikir bahwa mereka harus beralih ke bahasa masyarakat asli karena dianggap lebih berpengaruh bagi kelompoknya" (Hasil wawancara, 2017).

Pergeseran atau penyesuaian pada bahasa Minang ke bahasa Minang Pondok, dari pengamatan yang dilakukan dapat dibagi ke dalam tiga kelompok. Pertama, biasanya pengucapan dalam bahasa Minang Pondok cenderung menghilangkan vokal 'a' atau ' $i$ ' yang dalam bahasa Minang terletak di tengah atau di ujung kata, atau mengganti vokal itu dengan 'e' atau 'o'. Contohnya tampak pada tabel 1 .

Tabel 1 Penyesuaian Vokal 'a' atau 'i' dengan ' $e$ ' atau 'o' pada Bahasa Minang Pondok

\begin{tabular}{ccc}
\hline Bahasa & Bahasa & Bahasa Minang \\
Indonesia & Minang & Pondok \\
\hline Batuk & Batuak & Batok \\
Balik & Baliak & Balek \\
Sudut & Suduik & Suduk \\
\hline
\end{tabular}

Sumber: Observasi (2016/2017).

Kedua, biasanya verba dalam bahasa Minang yang pada bagian depannya berimbuhan "ma- , ta- , ba-"; di dalam bahasa Minang Pondok diganti dengan " me-, te- ,be-“" contohnya tampak pada tabel 2 .

Tabel 2 Penyesuaian awalan "ma-, ta-, ba-" menjadi "me-, te-, be-" pada Bahasa Minang Pondok

\begin{tabular}{ccc}
\hline Bahasa & Bahasa & Bahasa \\
Indonesia & Minang & $\begin{array}{c}\text { Minang } \\
\text { Pondok }\end{array}$ \\
\hline Terkilir & Takilok & Tekilok \\
Menjawab & Manjawek & Menjawek \\
Berjamur & Bacindawan & Becindawan \\
\hline
\end{tabular}

Sumber: Observasi (2016/2017).

Ketiga, imbuhan "-nyo" di belakang kata (nomina) pada bahasa Minang biasanya diganti menjadi "-nya", pada bahasa Minang Pondok. Contoh pemakaiannya tampak pada tabel 3 .
Tabel 3 Penyesuaian Imbuhan Belakang "-nyo" Menjadi "-nya" pada Bahasa Minang Pondok

\begin{tabular}{ccc}
\hline Bahasa & Bahasa & Bahasa Minang \\
Indonesia & Minang & Pondok \\
\hline Ayahnya & Apaknyo & Apaknya \\
Dia & Inyo & Inya \\
\hline
\end{tabular}

Sumber: Observasi (2016/2017).

Menurut Irawan, pergeseran bahasa bisa terjadi secara fonologis (bunyi), maupun morfologis (bentuk) (Irawan 2014). Kedua bentuk pergeseran ini ditemukan pada pola pergeseran bahasa Minang menjadi bahasa Minang Pondok ketika digunakan oleh orang Tionghoa. Beberapa contoh kata dalam bahasa Indonesia, bahasa Minang, dan bahasa Minang Pondok yang menunjukkan pergeseran sebagaimana paparan di atas, ditampilkan pada tabel 4.

Apa serta bagaimana seseorang berkomunikasi merupakan refleksi dari apa yang dipersepsi oleh kebudayaannya (Samovar, Porter, \& Jain, 1981). Perspektif dialektik mengasumsikan bahwa kebudayaan dan komunikasi saling terkait dan timbal balik. Artinya, kebudayaan mempengaruhi komunikasi, dan komunikasi merepresentasikan kebudayaan (Martin \& Nakayama, 2010). Bahasa sebagai bagian dari komunikasi, juga tidak terpisahkan dari kebudayaan. Baik bahasa dan kebudayaan dipelajari dan digunakan untuk meneruskan nilai-nilai, kepercayaan, persepsi-persepsi, dan norma-norma (Samovar, Porter, \& McDaniel, 2010). Itulah sebabnya, bahasa Minang Pondok juga merefleksikan kebudayaan Tionghoa, yang tampak khususnya dalam panggilan pada hubungan kekerabatan. Beberapa contoh panggilan dalam hubungan kekerabatan di dalam keluarga Tionghoa secara umum di Kota Padang dapat dilihat pada tabel 5.

Tabel 5 memperlihatkan bahwa orang Tionghoa di Kota Padang menggunakan bahasa Mandarin/Hokkian dan bahasa Minang Pondok dalam hubungan kekerabatan. Terdapat katakata bentukan yang berasal dari gabungan bahasa Mandarin/Hokkian dengan bahasa Minang, menjadi (yang disebut) bahasa Minang Pondok. Panggilan Kodang, Cidang, dan Icik misalnya, merupakan gabungan antara bahasa Mandarin/Hokkian dan bahasa Minang. Kodang 
Tabel 4 Contoh Kata-Kata dalam Bahasa Indonesia, Minang, dan Minang Pondok

\begin{tabular}{lll}
\hline $\begin{array}{l}\text { Bahasa } \\
\text { Indonesia }\end{array}$ & $\begin{array}{l}\text { Bahasa } \\
\text { Minang }\end{array}$ & $\begin{array}{l}\text { Bahasa } \\
\text { Minang } \\
\text { Pondok }\end{array}$ \\
\hline air & aia & aek \\
ambil & ambiak & ambek \\
aneh & ganjia & ganji \\
angkut & angkuik & angkuk \\
angsur & angsua & angsu \\
bawa & baok & bawak \\
bawel & nyinyia & nyinyi \\
cabut & cabuik & cabuk \\
campur & campua & campu \\
hitung & ituang & etong \\
\hline
\end{tabular}

Sumber: Observasi (2016/2017).

Tabel 5 Contoh Panggilan dalam Hubungan Kekerabatan pada Masyarakat Tionghoa di Padang

$\mathrm{BMP}=$ Bahasa Minang Pondok; $\mathrm{BMi}=$ Bahasa Minang; $\mathrm{BMH}=$ Bahasa Mandarin/Hokkian; $\mathrm{BI}=$ Bahasa Indonesia

\begin{tabular}{|c|c|c|c|}
\hline Glosari & Arti & BMP BMi & BMH BI \\
\hline Koko & $\begin{array}{l}\text { Kakak (Laki- } \\
\text { laki) }\end{array}$ & & $\sqrt{ }$ \\
\hline Cece & 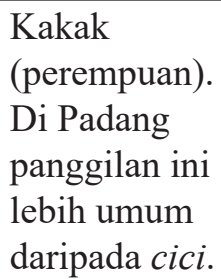 & & $\sqrt{ }$ \\
\hline Kodang & $\begin{array}{l}\text { Kakak Laki- } \\
\text { laki tertua } \\
\text { Koko }+ \\
\text { Gadang }\end{array}$ & $\sqrt{ }$ & \\
\hline Cidang & $\begin{array}{l}\text { Kakak } \\
\text { Perempuan } \\
\text { Tertua } \\
\text { Cici }+ \\
\text { Gadang } \\
\end{array}$ & $\sqrt{ }$ & \\
\hline$I i$ & Tante & & $\sqrt{ }$ \\
\hline Icik & $\begin{array}{l}\text { Tante paling } \\
\text { kecil } \\
I i+K e c i k\end{array}$ & $\sqrt{ }$ & \\
\hline Popoh & Nenek & & $\sqrt{ }$ \\
\hline $\begin{array}{l}\text { Akung/ } \\
\text { Engkong }\end{array}$ & Kakek & & $\sqrt{ }$ \\
\hline
\end{tabular}

Sumber: Observasi (2016/2017) berasal dari kata koko (kakak laki-laki, bahasa Mandarin/Hokkian) dan gadang (besar, bahasa Minang). Begitu juga Cidang, berasal dari kata cici (kakak perempuan, bahasa Mandarin/ Hokkian), dan gadang (besar, bahasa Minang). Sementara Icik, adalah bentukan dari Ii (bibi dalam bahasa Mandarin/Hokkian), dan kecik (kecil, bahasa Minang).

Jadi, bahasa yang digunakan dalam menyebutkan hubungan kekerabatan pada keluarga Tionghoa di Padang, antara lain merupakan campuran antara bahasa Mandarin/ Hokkian dan bahasa Minang. Bentukan istilah baru dari perkawinan bahasa Mandarin/Hokkian dan bahasa Minang itu, menjadi kekhasan panggilan dalam hubungan kekerabatan pada bahasa Minang Pondok. Bentukan serupa dengan yang terjadi pada bahasa Minang Pondok, ternyata juga ditemukan pada masyarakat Tionghoa di Pasuruan (Oetomo, 1987), yang misalnya, memanggil kakak perempuan tertua mereka dengan sebutan "cikde", gabungan antara cici (bahasa Mandarin/Hokkian) dengan gede (bahasa Jawa).

Kemiripan peristiwa adaptasi orang Tionghoa di Padang dan di Pasuruan memperlihatkan sensitivitas bahasa orang Tionghoa dalam menggambarkan kekerabatan, yang berpengaruh pada adopsi bahasa/adaptasi yang mereka lakukan. Orang Tionghoa sangat mementingkan hubungan keluarga, dan di dalam kebudayaan Tionghoa terdapat panggilan spesifik terhadap setiap anggota keluarga sesuai pangkat/derajat/senioritas orang yang bersangkutan di dalam keluarga. Panggilan juga dibedakan berdasarkan kekerabatan apakah dari pihak ibu atau dari pihak ayah. Sebagai contoh, kakak tertua akan dipanggil kakak pertama, dan seterusnya kakak kedua, kakak ketiga. Begitu juga berlaku untuk panggilan pada paman dan bibi. Panggilan ini juga akan berbeda antara kerabat dari pihak ayah atau pihak ibu. Pembedaan panggilan hubungan kekerabatan pada bahasa Mandarin/Hokkian itu juga diaplikasikan ketika berbicara dalam bahasa Minang Pondok.

Panggilan-panggilan yang spesifik menunjukkan kondisi dan kebudayaan Tionghoa sangat mempengaruhi bahasa yang digunakan dalam komunikasi sehari-hari. Situasi ini dijelaskan melalui teori relativitas linguistik yang juga dikenal dengan Hipotesis Sapir \& Whorf(Mulyana, 2015; Hussein, 2012). 
Menurut Sapir \& Whorf(Mulyana, 2015), setiap bahasa menunjukkan suatu dunia simbolik yang khas, yang melukiskan realitas pikiran, pengalaman batin, dan kebutuhan pemakainya. Itulah sebabnya, hubungan kekeluargaan yang penting dalam kebudayaan Tionghoa, terefleksi pada bahasa mereka melalui ekspresi panggilan.

Selain itu, panggilan dalam hubungan kekerabatan di dalam keluarga Tionghoa di Padang, ditentukanjuga oleh "tingkatketotokan" keluarga yang bersangkutan. Tingkat ketotokan biasanya dapat dilihat dari kemampuan keluarga itu dalam berbahasa Mandarin/ Hokkian, atau dialek lainnya, yang sebenarnya sudah tidak banyak lagi. Pada keluarga yang sudah tidak ada "orang tua" yang mengarahkan dalam hal panggilan kekerabatan sesuai tradisi Tionghoa, maka aplikasi panggilan sesuai derajat yang ada dalam kebudayaan Tionghoa biasanya akan hilang. Umumnya keluarga ini akan menyamakan semua panggilan, seperti misalnya " $I i$ " untuk semua bibi, atau "ntio" untuk semua paman. Tidak dapat dimungkiri kalau bahasa menunjukkan perhatian kultural pemakai bahasa itu. Menurunnya perhatian kultural orang Tionghoa terhadap kebudayaan mereka, cenderung menghilangkan sensitivitas mereka dalam menerapkan derajat/ normanorma pada panggilan kekerabatan.

Kelompok kebahasaan lain yang juga masih banyak menggunakan bahasa Mandarin/ Hokkian adalah nama-nama makanan. Banyak nama makanan sebenarnya merupakan kata serapan dari bahasa Mandarin/Hokkian ke dalam bahasa Indonesia, sehingga kasus ini tidak unik di Kota Padang saja. Beberapa contoh nama makanan yang sudah menjadi serapan dalam bahasa Indonesia dan sudah umum kita tahu misalnya, bakmi, kwetiau, bakso, bakwan, bihun (Hartati, 2012). Secara spesifik tidak ditemukan nama makanan yang merupakan bentukan/ pergeseran dari bahasa Minang menjadi bahasa Minang Pondok. Makanan khas Minang seperti lamang (lemang), tetapi disebut lamang oleh orang-orang Tionghoa. Namun yang menarik, ada beberapa makanan khas Tionghoa yang namanya berbeda di Padang dibandingkan di Pulau Jawa. Beberapa nama penganan di Kampung Pondok Padang yang berbeda dari di Jawa misalnya lumpiah di Jawa tetapi di Padang dikenal sebagai pokpiah, atau bakpia di Jawa, yang dikenal di Padang dengan sebutan kuepiah. Sedangkan penganan babi panggang, di Padang lebih populer siaobak (babi panggang putih), daripada di Jawa yang lebih akrab dengan casiu (babi panggang merah). Kelompok kata lain yang kadang-kadang memakai bahasa Mandarin/Hokkian dalam percakapan seharihari di Kota Padang adalah jumlah harga, seperti Seceng (seribu), cepek (seratus), gopek (lima ratus). Namun hal itu juga lazim ditemukan di kota-kota lain di Indonesia, khususnya di pusatpusat perdagangan. Sedangkan angka bilangan, umumnya memakai bahasa Minang.

Akhirnya, bahasa Minang Pondok diakui oleh informan-informan sangat penting dalam merekatkan hubungan antara etnik Tionghoa dan etnik Minang. Kompetensi orang-orang Tionghoa dalam bahasa Minang Pondok membuat mereka lebih bisa berbaur dengan masyarakat mayoritas Minang. Salah seorang informan, dosen beretnik Minang (Un), mengatakan bahwa orang Tionghoa di Kota Padang relatif soft/ lunak (dibandingkan dengan orang Tionghoa di salah satu kota tetangga). Pendapat informan (Un) itu, terkait dengan kenyataan bahwa orang Tionghoa di Padang lebih bisa berbaur, dan hal itu didukung oleh kompetensi mereka dalam berbahasa Minang. Bahasa Minang, pada dasarnya menjadi bahasa yang mempersatukan aneka suku bangsa di Kota Padang yang merupakan kota perantauan.

Penggunaan bahasa Minang Pondok dalam komunikasi masyarakat Tionghoa di Kota Padang merupakan bentuk pengaruh etnik Minang terhadap etnik Tionghoa, sekaligus bukti penyesuaian/adaptasi yang dilakukan oleh etnik Tionghoa terhadap etnik mayoritas untuk mencapai saling pengertian dalam komunikasi antarbudaya. Penyesuaian menjadi kata kunci dalam hubungan antaretnik, bahkan komunikasi suami isteri. Novianti mengatakan pada pasangan suami isteri Sunda dan Minang, lebih sering memakai bahasa Indonesia sebagai bentuk kompromi/titik tengah (Novianti, 2014). Adaptasi lewat adopsi bahasa ini dalam perspektif akulturasi merupakan proses pembelajaran untuk hidup di dalam budaya baru. Bagaimanapun, budaya manusia dengan segala kerumitannya tidak akan berkembang dan tidak dapat dipikirkan tanpa bantuan bahasa (Samovar, Porter, \& McDaniel, 2010). Martin \& Nakayama menyebutkan komunikasi membantu menciptakan kebudayaan dari sebuah komunitas (Martin \& Nakayama, 2010). Sejalan dengan itu, komunikasi orang Tionghoa 
di Padang, menciptakan kebudayaan yang memperlihatkan campuran antara Tionghoa dan Minang melalui bahasa Minang Pondok.

\section{SIMPULAN}

Bahasa berperan besar dalam komunikasi antarbudaya. Pergeseran/penyesuaian bahasa ketika diadopsi dan digunakan oleh kelompok minoritas menciptakan keunikan yang menjadi daya tarik, dan tidak perlu dipermasalahkan. Seperti di Kota Padang, komunikasi orang Tionghoa dalam bahasa Minang Pondok menjadi ciri khas komunitas. Komunikasi lewat bahasa Minang Pondok juga mendukung terbentuknya saling pengertian dan hubungan yang lebih kondusif antara etnik Tionghoa dengan etnik mayoritas Minangkabau. Belajar dari Kota Padang, pemahaman mengenai bahasa dalam interaksi antarkelompok berbeda sangat esensial untuk menjaga keharmonisan dan persatuan negara dan bangsa Indonesia yang multietnik. Di sisi lain, bahasa kelompok minoritas harus dijaga/dipertahankan, karena bahasa menunjukkan identitas dan merupakan kekayaan kultural. Kemampuan dwibahasa (bahasa ibu/etnik dan bahasa nasional), bahkan tribahasa (ditambah bahasa asing) hendaknya bisa menjadi tren bagi generasi baru Indonesia yang modern.

\section{DAFTAR PUSTAKA}

Alfirdaus, L. K., Hiariej, E., \& AdeneyRisakotta, F. (2016). The position of minang-chinese relationship in the history of inter-ethnic groups relations in padang, west sumatra. Humaniora, Vol. 28, No. 1 Februari 2016.

\section{.(2014). Politik relasi}

etnik: matrilinealitas dan etnik minoritas cina di padang, sumatra barat. Jurnal Komunitas 6 (1) (2014): 136-150.

Anggraeni, D. (2017). Chinese indonesians after may 1998 how they fit in the big picture. Wacana Vol. 18 No. 1 (2017): 106-130.

Arka,I. W.(2011). Kompleksitas, pemertahanan, dan revitalisasi bahasa dan budaya minoritas. Edisi xxxvii / no.1 / 2011 | 35. Masyarakat Indonesia, 2017 - jmi.ipsk.lipi. go.id [12 September 2018].

Barth, F. (1998). Ethnic groups and boundaries.
Melalui: http:/graduateinstitute.ch/files/ live/sites/iheid/files/sites/mia/shared/mia/ cours/IA010/Barth\%20Introduction $\% 20$ Ethnic \% 20 Groups \% 20 and $\% 20$ Boundaries\%20.pdf [12/15/2016].

BadanPusatStatistik.(2011).Kewarganegaraan, sukubangsa, agama, dan bahasa seharihari penduduk indonesia hasil sensus penduduk 2010. Badan Pusat Statistik Jakarta-Indonesia.

BNPB. (2017). Peta administrasi kota padang. Diakses dari http://geospasial.bnpb. go.id/2009/10/13/peta-administrasi-kotapadang/.

BPS Kota Padang. (2016). Kota padang dalam angka 2016. Badan Pusat Statistik Kota Padang.

(2011). Pengolahan hasil sensus penduduk kota padang 2010. Badan Pusat Statistik Kota Padang.

Chang-Yau H. (2006). Assimilation, multiculturalism, hybridity: the dilemmas of the ethnic chinese in post-soeharto indonesia. Asian Ethnicity, Volume 7, Number 2, June 2006.

Creswell, J. W. (2014). Penelitian kualitatif \& desain riset. Ahli bahasa Ahmad Lintang Lazuardi. Pustaka Pelajar.

Dahana, A. (2015). Indonesian peranakan chinese: the origins and their culture. Melalui http://chinese.binus. ac.id/2015/02/18/indonesian-peranakanchinese-the-origins-and-their-culture-byprof-a-dahana/ [08/04/16].

Denzin, N. K. \& Lincoln, Y. S. (2009). Handbook of qualitative research. Sage Publication.

Elfira, M. (2011). Inter-ethnic relations in padang of west sumatra navigating between assimilation and exclusivity. Wacana, Vol. 13 No. 2 (Oktober 2011): 293 - 304.

Erniwati. (2016). 140 Tahun heng beng tong sejarah perkumpulan tionghoa 1876-2016. Komunitas Bambu.

7 Desember 2011. Cina padang, berbahasa minang logat mandarin. Melalui: $\quad$ http://www.jpnn.com/ $\mathrm{read} / 2011 / 12 / 07 / 110504 /$ Cina-Padang,Berbahasa-Minang-Logat-Mandarin$[4 / 25 / 16]$.

Gao, M. C. F. (2000). Influence of native culture and language on intercultural communication: the case of prc student 
immigrants in australia. Intercultural Communication, ISSN 1404-1634, 2000, November, issue 4. Melalui: https:// www.immi.se/intercultural/nr4/gao.htm [09/16/18].

Hapsari, A. (2013). Brief analysis of apology in pondok village, padang, west sumatera. Journal of English and Education, Vol. 7 No. 1 - June 2013.

Hartati, C. D. (2012). Akulturasi budaya cina dan betawi di jakarta. Prosiding seminar hasil penelitian semester genap 2012/2013. Universitas Darma Persada. Melalui: Lp2mk.Unsada.Ac.Id/Wp-Content/ Uploads/2016/04/Prosiding-Gj1-11-12.Pdf (3 Mei 2017)

Heryadi, H. \& Silvana, H. (2013). Komunikasi antarbudaya dalam masyarakat multikultur. Jurnal Kajian Komunikasi, Volume 1, No. 1, Juni 2013, Hlm 95-108.

Hussein, B. A. (2012). The sapir-whorf hypothesis today. Theory and Practice in Language Studies, Vol. 2, No. 3, pp. 642646, March 2012.

Irawan, Y. N. (2014). Pergeseran bahasa mandarin dialek hokkian pada keluarga etnis cina benteng di kelurahan sukasari, tangerang. Program studi bahasa dan sastra indonesia, Fpbs, UPI. Melalui: http:// ejournal.upi.edu/index.php/BS_Antologi_ Ind/article/view/527/404 [5/3/17].

Jelprison. 1 November (2010). Susah mencari pengguna bahasa melayu di pekanbaru. Melalui: https://kampungrison.wordpress. com/2010/11/01/susah-mencari-penggunabahasa-melayu-di-pekanbaru/ [10/13/17].

Lubis, L. A. (2012). Komunikasi antarbudaya tionghoa dan pribumi dalam penggunaan bahasa. Jurnal Ilmu Komunikasi, Volume 10, Nomor 3, Agustus 2012, hlm. 285-294.

Martin, J. N. \& Nakayama, T. K. (2010). Intercultural communication in contexts. Fifth Edition. McGraw Hill.
Moleong, L. J. (2015). Metodologi penelitian kualitatif. Bandung: Remaja Rosdakarya.

Mulyana, D. (2015). Ilmu komunikasi suatu pengantar. Bandung: Remaja Rosdakarya.

Novianti, E. (2014). Pola komunikasi pasangan antaretnik sunda-minang di bandung. Jurnal Kajian Komunikasi, Volume 2, No. 2, Desember 2014, Hlm 95-108. Hlm 161172.

Oetomo, D. (1987). The chinese of pasuruan: their language and identity. Department Of Linguistics, Research School Of Pacific Studies The Australian National University. Melalui: http://pubman.mpdl.mpg.de/ pubman/item/escidoc:402745/component/ escidoc:402744/pasuruan_oetomo1987_o. pdf $[6 / 15 / 17]$

Rachmazan, S. (2017). Eksistensi bahasa melayu di kota pekanbaru. JOM FISIP Vol. 4 No. 1 - Februari 2017.

Samovar, L. A., Porter, R. E., \& McDaniel, E. R. (2010). Komunikasi lintas budaya. Edisi 7. Penerjemah Indri Margaretha Sidabalok, S.S. Salemba Humanika. , \& Jain, N. C. (1981). Understanding intercultural communication. Wadsworth Publishing Company.

Septia, E (2017). Bahasa pedagang etnis cina dalam interaksi jual beli di pasar pondok kota padang: kajian sosiolinguistik. Jurnal Gramatika Jurnal Penelitian Bahasa dan Sastra Indonesia V3.i1 (1-8).

Setijadi. (2017). Chinese indonesians in the eyes of the pribumi public. ISEAS Yusof Ishak Institute, No. 73.

Sugiyono. (2015). Memahami penelitian kualitatif. Bandung: Alfabeta.

Suryadinata, L. (2018). Ethnic groups and the indonesian nation-state. Di dalam Routledge Handbook of Contemporary Indonesia. Routledge. Accessed on: 10 Sep 2018 https://www.routledgehandbooks. com/doi/10.4324/9781315628837-3. 